\title{
Impact and Factors Associated with Presbycusis among 50 Years Old People of Parakou and Over in 2021
}

\author{
Marius Claude Flatin1,2*, Alexis AWC do Santos Zounon33, Cocouvi Bruno Ametonou'2, \\ Fatiou Alabi Bouraima1,2, Méré Roland Kimba ${ }^{1}$, Spéro HR Hounkpatin ${ }^{1,2}$, Wassi Adjibabi ${ }^{3}$, \\ Bernadette Vignikin-Yehouessi ${ }^{3}$
}

${ }^{1}$ Faculté de Médecine, Université de Parakou, Parakou, Bénin

${ }^{2}$ Centre Hospitalier Universitaire et Départemental Borgou, Parakou, Bénin

${ }^{3}$ Faculté des Sciences de la Santé, Université d’Abomey Calavi, Cotonou, Bénin

Email: ^drflatinmarius@gmail.com

How to cite this paper: Flatin, M.C., do Santos Zounon, A.A., Ametonou, C.B., Bouraima, F.A., Kimba, M.R., Hounkpatin, S.H., Adjibabi, W. and Vignikin-Yehouessi, B. (2022) Impact and Factors Associated with Presbycusis among 50 Years Old People of Parakou and Over in 2021. International Journal of Otolaryngology and Head \& Neck Surgery, 11, 56-73.

https://doi.org/10.4236/ijohns.2022.111007

Received: December 7, 2021

Accepted: January 25, 2022

Published: January 28, 2022

Copyright $\odot 2022$ by author(s) and Scientific Research Publishing Inc. This work is licensed under the Creative Commons Attribution International License (CC BY 4.0).

http://creativecommons.org/licenses/by/4.0/ (c) (i) Open Access

\begin{abstract}
Introduction: Presbycusis or age-related hearing loss is a condition of insidious onset with significant socio-professional repercussions. The objective of this study was to determine the impact and factors associated with presbycusis among 50 years aged people or older in Parakou commune during 2021. Methods: This was a cross-sectional, descriptive, analytical study with prospective data collection. The study has involved 54150 years aged people or older, from February to May 2021. For each of them, a questionnaire was completed, otoscopy and tone audiometry performed. The ERSA questionnaire and the logistic regression model were used to determine the impact and factors associated with presbycusis. Results: The mean age was $59.48 \pm$ 9.80 years and the sex ratio was 1.23 . The prevalence of presbycusis was $50.28 \%$. Age $\geq 80$ years $(p=0.002)$, male sex $(p=0.016)$, low educational level $(p=0.001)$, family history of age-related hearing loss $(p=0.018)$ and presence of hearing loss $(p=0.001)$ were significantly associated with presbycusis in multivariate analysis. Of the life domains studied, personal life (mean score $=32.9 \pm 10.52$ ) was the most affected. Similarly, communication in a noisy environment (mean score $=4.39 \pm 2.39$ ) was the most affected aspect of personal life. Conclusion: Presbycusis leads to an impairment of personal life. A good knowledge of the associated factors and an early management could contribute to the improvement of the hearing health of the elderly.
\end{abstract}

\section{Keywords}

Presbycusis, Elderly, Hearing, Deafness 


\section{Introduction}

Normal aging is a set of molecular, histological, physiological and psychological processes that accompany advancing age. In terms of hearing, this aging results in a neurosensorial damage responsible for a progressive bilateral sensorineural hearing loss called presbycusis [1]. It is the most frequent sensory deficit in the world [2] and its prevalence increases with age.

With the increase in life expectancy, it is obvious that presbycusis will increase in the coming years. Indeed, the population aged over 60 years will increase from 605 million in the year 2000 to 2 billion in 2050 [3]. In Africa, this number will increase from 56 to 215 million, almost as many as in Europe [4].

The onset of presbycusis may be accelerated by certain factors. Davanipour et al. [5] identified in their survey certain risk factors such as alcohol and tobacco consumption, high blood pressure and low socio-economic status. Studies have shown a higher prevalence in men than in women [5] [6].

Complications of presbycusis can be severe. Presbycusis can induce character disorders (anxiety, apathy, ...), mood disorders (depression), communication disorders, isolation and cognitive disorders [7] [8].

In view of all these considerations, the diagnosis of presbycusis and its management represent major public health issues in developing countries. The lack of existing data on this subject in Benin, and more specifically in Parakou town, motivated the present study, the objectives of which were: 1) to identify the factors associated with presbycusis among people of Parakou aged at least 50 years in $2021 ; 2)$ to evaluate its socio-professional impact.

\section{Methods}

This was a cross-sectional, descriptive, analytical study with prospective data collection, from February to May 2021, i.e. 04 months.

Were included in the study, people:

- aged 50 years and more;

- residing for at least six (06) months in the commune of Parakou in the course of the survey;

- who gave their consent to participate in the study.

Were not included in the study, people:

- who were absent or busy during survey team visitation;

- who objected to the performance of a pure tone audiometry;

- exposed to loud noise because of their work;

- who were ill and unable to answer questions promptly.

Were excluded from the study:

- people who had withdrawn at any time during data collection;

- people who had an abnormal otoscopic examination.

The sample was probabilistic, obtained through a four-stage cluster random sampling. In the first stage, clusters were selected from the city neighborhoods. In the $2^{\text {nd }}$ stage, concessions were selected; in the $3^{\text {rd }}$ and $4^{\text {th }}$ stages, households 
and individuals per household were selected (respectively). The sampling list consisted of the 42 neighborhoods of Parakou commune accompanied by their respective household counts; as presented by the $4^{\text {th }}$ General Census of Population and Housing (RGPH 4) conducted by INSAE in 2013 [9].

The Schwartz formula was used to determine the sample size (n).

$$
n=k * Z \alpha_{2} * p *(1-p) i^{2}
$$

With:

$\alpha=0.05$ : first-species risk, hence $Z \alpha=1.96$;

$p=22.7 \%$ (Prevalence of presbycusis in Egypt) [10];

$i=5 \%$ : the desired precision;

$n$ : the expected sample size;

$k=2$ : cluster effect;

$n=540$.

The variables studied were:

- presbycusis;

- socio-demographic variables;

- functional signs;

- medical history;

- lifestyle;

- audiometry result;

- socio-professional impact.

\section{Diagnostic criteria}

Presbycusis was retained when the following criteria were met:

- an age equal or superior to 50 years;

- the presence or absence of auditory discomfort reported on questioning;

- a normal otoscopic examination ;

- a sensorineural bilateral and symmetrical deafness (average hearing loss $>20$ dB HL).

Symmetry was defined as a difference in perception between the two ears of less than $10 \mathrm{~dB}$ on the audiometric frequencies between 500 and $4000 \mathrm{~Hz}$ [11].

Data collection

The data collection tools were: a survey questionnaire, a HEINE Mini 3000 otoscope with $2.5 \times$ magnification, and a portable AUDIOSMART audiometer with a 3 - 4 hours measurement autonomy.

The socio-professional impact was assessed using the questionnaire "Evaluation of the impact of hearing loss in adults" [12]. The questionnaire includes four domains, "Quality of life", "Personal life", "Social life" and "Professional life". Each domain consists of five questions written in a precise and short manner, in a common vocabulary and without negative wording. For each question, a visual analogue scale proposes a response from 0 to 10, allowing a quick count. The score 0 corresponds to a maximum difficulty, the score 10 to an ideal situation. The scores are averaged for each life domain. This average, for each domain, has a maximum value of 50 and a minimum value of 0 . The lower the av- 
erage, the greater the impact of the deafness on this area of life.

The data collection technique consisted of:

- an individual interview with each respondent;

- an otological examination of each respondent;

- a tonal audiometry.

Data processing and analysis

After collection, the data were verified, coded and then entered into EPI data 3.1.fr software. Data analysis was processed by the medium of Epi info 7.2.0.1. The qualitative variables were expressed in number and percentage and the quantitative variables in mean \pm standard deviation or median with the first and third quartile depending on whether the distribution was normal or not. The comparison of proportions was performed with the Pearson Chi-square test or Fisher's exact test, as appropriate. The comparison of quantitative variables was performed with the Student's test or the Kruskal-Wallis test, depending on whether the distribution was normal or not. A p-value of less than 0.05 allowed the recognition of statistically significant associations in univariate analysis.

Binary logistic regression was performed to adjust for associated factors. The initial multivariate analysis model included the associated variables in univariate analysis at a threshold of $\mathrm{p}<0.2$.

\section{Results}

A total of 541 people were included in this study.

\section{Prevalence of presbycusis}

Of the 541 persons who participated in the present study, the diagnosis of presbycusis was retained in 272 , for a prevalence of $50.28 \%$.

\section{Characteristics of the respondents}

The sex ratio (male/female) was 1.23. The average age was $59.48 \pm 9.80$ years with extremes of 50 and 96 . Most of the respondents (71.11\%) were exposed to noise.

Figure 1 shows the distribution of the respondents according to the type of

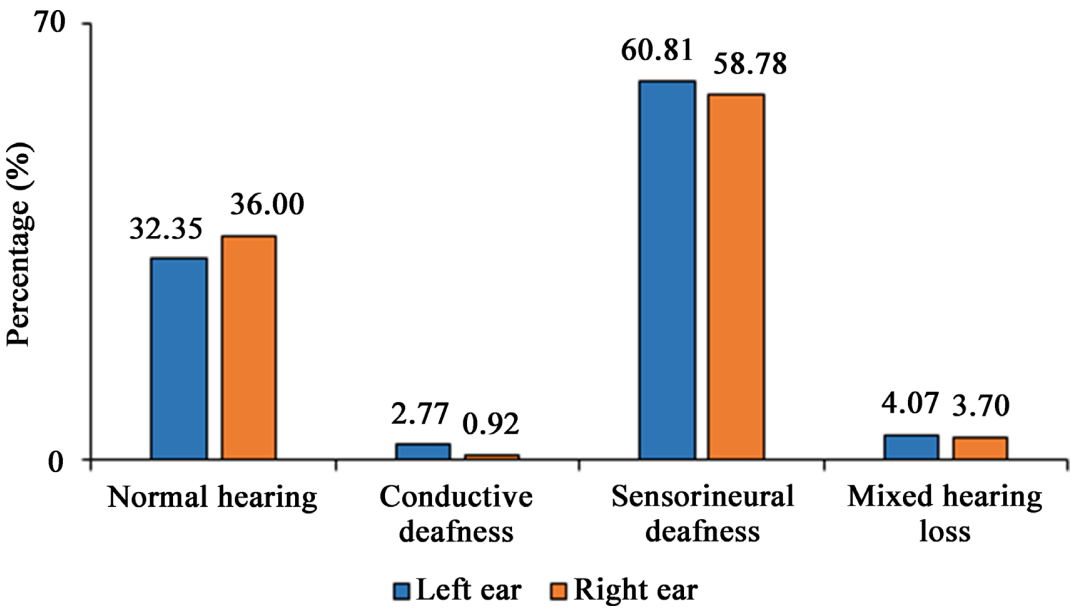

Figure 1. Distribution according to the type of deafness, of people aged at least 50 years in the commune of Parakou; February-May $2021(n=541)$. 
hearing loss found.

As for the degree of deafness of the population studied, mild deafness was the most common. It was present in $56.56 \%$ of the respondents in the left ear and in $52.31 \%$ of the respondents in the right ear. On the right and left ears respectively, the moderate, severe and profound degrees represented $15.07 \%$ and $15.50 \%$; $0.27 \%$ and $1.46 \% ; 0.82 \%$ and $0.29 \%$.

The other characteristics are shown in Table 1.

In univariate analysis, there was a significant association between presbycusis and certain socio-demographic variables (Table 1$)$. There was also a significant association with hearing loss $(\mathrm{p}<0.001)$, tinnitus $(\mathrm{p}=0.004)$, vertigo $(\mathrm{p}=$ $0.078)$, osteoarthritis $(\mathrm{p}=0.024)$, family history of age-related hearing loss $(\mathrm{p}=$ $0.009)$, alcoholism ( $\mathrm{p}=0.009)$, smoking $(\mathrm{p}=0.004)$.

Table 1. Influence of various factors in the onset of presbycusis in people aged at least 50 years in Parakou; February-May $2021(\mathrm{n}=272)$.

\begin{tabular}{|c|c|c|c|c|c|c|}
\hline & \multirow{2}{*}{$\mathbf{N}$} & \multicolumn{2}{|c|}{ Presbycusis } & \multirow{2}{*}{ df } & \multirow{2}{*}{$x^{2}$} & \multirow{2}{*}{$\mathrm{p}$-value } \\
\hline & & $\mathbf{n}$ & $\%$ & & & \\
\hline \multicolumn{7}{|l|}{ Age } \\
\hline$[50-60[$ & 306 & 122 & 39.87 & 3 & 41.09 & $<0.001$ \\
\hline$[60-70[$ & 151 & 88 & 58.28 & & & \\
\hline$[70-80[$ & 53 & 34 & 64.15 & & & \\
\hline$\geq 80$ & 31 & 28 & 90.32 & & & \\
\hline \multicolumn{7}{|l|}{ Gender } \\
\hline Female & 242 & 106 & 43.80 & 1 & 7.34 & 0.007 \\
\hline Male & 299 & 166 & 55.52 & & & \\
\hline \multicolumn{7}{|l|}{ Profession } \\
\hline Craftsman & 105 & 52 & 49.52 & 8 & 15.91 & 0.044 \\
\hline Shopkeeper & 81 & 39 & 48.15 & & & \\
\hline Farmer & 62 & 35 & 56.45 & & & \\
\hline Entrepreneur & 13 & 5 & 38.46 & & & \\
\hline Housewife & 113 & 49 & 43.36 & & & \\
\hline Retired & 125 & 77 & 61.60 & & & \\
\hline Private employee & 3 & 1 & 33.33 & & & \\
\hline Public employee & 28 & 12 & 42.86 & & & \\
\hline Other & 11 & 2 & 18.18 & & & \\
\hline \multicolumn{7}{|l|}{ Level of education } \\
\hline Illiterate & 15 & 6 & 40.00 & 4 & 16.11 & 0.003 \\
\hline Literate & 187 & 111 & 59.36 & & & \\
\hline Primary & 151 & 77 & 50.99 & & & \\
\hline
\end{tabular}




\section{Continued}

$\begin{array}{lccc}\text { Secondary } & 149 & 67 & 44.97 \\ \text { University } & 39 & 11 & 28.21\end{array}$

\section{Noise exposure}

$\begin{array}{lcccccc}\text { No } & 384 & 182 & 47.40 & 1 & 4.14 & 0.042 \\ \text { Yes } & 156 & 89 & 57.05 & & & \end{array}$

\section{Hearing loss}

$\begin{array}{lllllll}\text { No } & 376 & 167 & 44.41 & 1 & 16.95 & <0.001 \\ \text { Yes } & 165 & 105 & 63.64 & & & \end{array}$

\section{Tinnitus}

$\begin{array}{lcccccc}\text { No } & 282 & 125 & 44.33 & 1 & 8.34 & 0.004 \\ \text { Yes } & 259 & 147 & 56.76 & & & \\ \text { Vertigo } & & & & & & \\ \text { No } & 203 & 112 & 55.17 & 1 & 3.11 & 0.078 \\ \text { Yes } & 338 & 160 & 47.34 & & & \\ \text { HBP } & & & & & & \\ \text { No } & 433 & 215 & 49.65 & 1 & 0.34 & 0.561 \\ \text { Yes } & 108 & 57 & 52.78 & & & \end{array}$

\section{Osteoarthritis}

$\begin{array}{lcccccc}\text { No } & 494 & 241 & 48.79 & 1 & 5.06 & 0.024 \\ \text { Yes } & 47 & 31 & 65.96 & & & \end{array}$

Family history of age-related hearing loss

$\begin{array}{lcccccc}\text { No } & 406 & 191 & 47.04 & 1 & 6.80 & 0.009 \\ \text { Yes } & 135 & 81 & 60.00 & & & \end{array}$

\section{Alcoholism}

$\begin{array}{lcccccc}\text { No } & 442 & 211 & 47.74 & 2 & 9.44 & 0.009 \\ \text { Yes } & 86 & 56 & 65.12 & & & \\ \text { Stop } & 13 & 5 & 38.46 & & & \\ \text { Smoking } & & & & & & \\ \text { No } & 385 & 185 & 48.05 & 2 & 10.90 & 0.004 \\ \text { Yes } & 107 & 68 & 63.55 & & & \\ \text { Stop } & 49 & 19 & 38.78 & & & \end{array}$

$\mathrm{df}=$ degree of freedom; HBP = high blood pressure.

From the multivariate analysis, it appears that the occurrence of presbycusis in adults in Parakou commune within 2021 is a function of age, sex, the presence of hypoacusis and the presence of a family history of age-related hearing loss (Table 2). 
Table 2. Model of the multivariate analysis of factors associated with presbycusis in the commune of Parakou; February-May $2021(n=272)$.

\begin{tabular}{lccc}
\hline & aOR & {$[95 \% \mathrm{CI}]$} & p-value \\
\hline Age & & & \\
{$[50-60[$} & 1.00 & - & - \\
{$[60-70[$} & 1.86 & {$[1.23-2.82]$} & 0.003 \\
{$[70-80[$} & 1.76 & {$[0.91-3.80]$} & 0.090 \\
$\geq 80$ & 7.61 & {$[2.15-26.87]$} & 0.002
\end{tabular}

\section{Gender}

Female

Male

Noise exposure

No

Yes

\section{Hearing loss}

No

Yes

2.02

Tinnitus

No

Yes

Vertigo

No

Yes

Level of education

Illiterate

2.18

4.12

Literate

Primary

3.27

Secondary

2.40

University

1.00

Family history of age-related hearing loss

No

Yes

1.00

1.67

[0.06 - 0.31]

0.018

\section{Osteoarthritis}

$$
\text { No }
$$

Yes

Alcoholism

1.00

[1.09-2.33]

0.016

$[0.93-2.24]$

0.105

$\begin{array}{lll}.44 & {[0.93-2.24]} & 0.105\end{array}$

19

$[0.8-1.77]$

0.391

1.00

1.05

$[0.7-1.58]$

0.813

[0.59-8.08] 0.244

[1.82- 9.35] 0.001

[1.46- 7.34] 0.004

$[1.07-5.38] \quad 0.033$

$-$

Alcoholism 


\begin{tabular}{cccc} 
Continued & & & \\
\hline Stop & 1.03 & {$[0.27-3.88]$} & 0.964 \\
Yes & 1.78 & {$[0.97-3.29]$} & 0.064 \\
No & 1.00 & & \\
Smoking & & & \\
Yes & 2.51 & {$[1.13-5.57]$} & 0.023 \\
No & 2.53 & {$[1.2-5.34]$} & 0.015 \\
Stop & 1.00 & & \\
\hline
\end{tabular}

Thus, when adjusted for other factors, people over 80 years of age were nearly 8 times more likely to develop presbycusis than those aged 50 to 60 years. Similarly, men were 1.59 times more likely than women. The risk of developing presbycusis was inversely proportional to the level of education.

The average scores obtained for different aspects of personal life among presbycusic people in Parakou are as follows: communication with relatives $6.97 \pm$ 2.26; following a conversation without knowing the topic $7.24 \pm 2.43$; participation in a conversation with several people, in a quiet environment $6.76 \pm 2.57$; discussion in a noisy environment (family meeting, meal with television, ...) 4.39 \pm 2.39 ; self-confidence to initiate a discussion with relatives $7.53 \pm 2.84$. The aspect of personal life most affected was communication in noise.

\section{Discussion}

\section{Prevalence of presbycusis}

The prevalence of $50.28 \%$ found in the present study is close to those observed by Cruickshanks et al. in the United States in 2012 as well as Valero-Garcia et al. in Spain in 2018 who had reported prevalences of $42.7 \%$ and $54.87 \%$ respectively [13] [14].

It is however, lower than that reported by Lin et al. in the United States in 2011, Folorunso et al. in Nigeria in 2020 who had reported prevalences of $63 \%$ and $75 \%$ respectively [15] [16]. Similarly, lower prevalences had been found by Nash et al. in the United States in 2011 and Hannula et al. in Finland in 2011 who had reported prevalences of $6.1 \%, 14.1 \%$, and $37 \%$ respectively [17] [18].

This large variability could be explained by the fact that there are very large differences in the method and diagnostic criteria used.

Indeed, the definition of deafness varied from one study to another. In the present study, we used the BIAP classification while other authors used the WHO classification [19]. Clearly, the lack of a common definition prevents the availability of comparable data on the prevalence of presbycusis.

The age ranges of the subjects surveyed differed from one study to another. There are no recommendations regarding the age limit for presbycusis. The choice of the age range of the study population was in most cases arbitrary and 
the reasons for this choice were not often mentioned.

It should also be noted that the size of the target populations and the type of study were very different from each other. Nash et al. [17] conducted a cohort study with more than 3000 volunteers, whereas the study by Folorunso et al. [16] was a cross-sectional study with 114 volunteers.

\section{Factors associated with presbycusis}

In the present study, age was significantly associated with presbycusis and the prevalence of presbycusis increased with age. For example, subjects over 80 years of age were at least 8 times more likely to develop presbycusis than younger subjects. This finding corroborates that of Cruickshanks et al. [14] in the United States in 2012 and Lasisi et al. [20] in Nigeria in 2010. This association of age and presbycusis found by several studies could be explained by the aging of the hearing system. Indeed, the contingent of sensory cells (less than 20,000 hair cells per cochlea) that we are endowed with at birth is limited and non-renewable. This contingent diminishes irreversibly over the years [21].

Gender was significantly associated with presbycusis. The prevalence of presbycusis was higher among male subjects. This finding has been made by many authors [8] [15] [22]. This male predominance could be explained by several factors: the protective role of female hormones [23] [24], the difference in exposure to other exogenous factors that may favor the occurrence of presbycusis. Indeed, men are more exposed to noise than women from a very young age. Even more men than women work in construction, factories, mechanics or welding. The same applies to the other factors of smoking and alcohol consumption [25].

Educational level was significantly associated with presbycusis in the present study. Indeed, illiterate subjects were up to 4 times more likely to develop presbycusis than subjects with a university education. This finding is similar to that of several authors [14] [17] [26]. Indeed, a high level of education would represent an indicator of socio-economic status which is also indicative of better access to health care, a healthier environment and less stress at work. On the other hand, a low socio-economic level would be more likely to lead to cardiovascular disease, which is a risk factor for presbycusis [18].

In the present study, only osteoarthritis was significantly associated with presbycusis. This factor was also found by Sogebi et al. [26] in Nigeria in 2013. This association could be explained by the fact that osteoarthritis is an inflammatory disease and the autoimmune mechanisms it involves, could contribute to the progressive destruction of the inner ear [27].

From the results of the study, a family history of age-related hearing loss was associated with presbycusis. These data have met the requirements of those of Bouata et al. [28] who also reported a statistically significant association between presbycusis and a family history. This could be explained by the fact that genetic factors are involved in the occurrence of presbycusis. Indeed, several studies have investigated this link and have identified a number of genetic variants with 
a statistical correlation that suggests that they may be involved in the development of presbycusis [29] [30].

\section{Impact of presbycusis}

In this survey,, all areas of life were impacted by presbycusis. The most impacted life domain was personal life. Several studies have shown that the first area to be affected once overt presbycusis is reached is the family area [28] [31] [32]. This could be explained by the fact that family members are the first to notice hearing difficulties. The patient, on the other hand, does not realize that he or she cannot hear well. This observation implies that the family and friends play a crucial role in the early detection of presbycusis. A diagnosis at this stage would allow an early management of presbycusis which could avoid the evolution towards complications.

In this research work, the aspect of personal life most affected was communication in noise. This finding was also presented by Espmark et al. [33] and Bouata et al. [28]. Indeed, presbycusis leads to a discomfort in noise which is characterized by a difficulty to follow a conversation in a group or in a noisy environment realizing the classic sign of the "cocktail". The subject has the impression of hearing very well, even too well, especially motorcycles or any other violent noise. This phenomenon is explained by the fact that his painful threshold for high intensity sounds is confused, or almost, with his/her hearing threshold [34].

\section{Strengths and weaknesses}

This study has several strengths. It was conducted in a general population. Such type of study is the most relevant for determining the prevalence of a condition in the community. Method used was appropriate and the material collection was reliable. However, the study had some shortcomings: the audiometry was carried out in the respondents' homes, a setting in which the noise level was unknown, even though the examination was carried out away from any sound source. Voice audiometry was not performed. It could have provided additional data to better refine the diagnosis of presbycusis.

\section{Conclusion}

The prevalence of presbycusis was high among people over 50 years old in $\mathrm{Pa}$ rakou commune during 2021. Factors associated with presbycusis were: age $\geq 80$ years, male gender, educational level, family history of age-related hearing loss. The associated sign was hearing loss. Presbycusis had a negative impact on all areas of life but impacted more, the personal life of the affected subjects. Controlling and addressing the associated factors could significantly contribute to reducing the prevalence of presbycusis, improving the hearing health of elderly subjects.

\section{Conflicts of Interest}

The authors declare no conflicts of interest regarding the publication of this paper. 


\section{References}

[1] Bouccara, D., Ferrary, E., Mosnier, I., Bozorg Grayeli, A. and Sterkers, O. (2006) Presbyacousie. EMC-Oto-rhino-laryngologie, 1, 1-9. https://doi.org/10.1016/S0246-0351(05)39239-7

[2] Mathers, C., Smith, A. and Concha, M. (2000) Global Burden of Hearing Loss in the Year 2000. Global Burden of Disease, 18, 1-30.

https://www.who.int/healthinfo/statistics/bod hearingloss.pdf

[3] World Health Organization (2012) Statistiques démographiques et socio-économiques. In: World Health Stat., Ed., Statistiques Sanitaires Mondiales 2012, World Health Organization, Genève, 157-168.

http://apps.who.int/iris/bitstream/handle/10665/44857/9789242564440 fre.pdf?seq uence $=1$

[4] Le Temps (2012) L'Afrique face au vieillissement rapide de sa population. https://www.letemps.ch/sciences/lafrique-face-vieillissement-rapide-population

[5] Davanipour, Z., Lu, N.M., Lichtenstein, M. and Markides, K.S. (2000) Hearing Problems in Mexican American Elderly. American Journal of Otolaryngology, 21, 168172.

[6] Cruickshanks, K.J., Wiley, T.L., Tweed, T.S., Klein, B.E., Klein, R., Mares-Perlman, J.A., et al. (1998) Prevalence of Hearing Loss in Older Adults in Beaver Dam, Wisconsin. The Epidemiology of Hearing Loss Study. American Journal of Epidemiology, 148, 879-886. https://doi.org/10.1093/oxfordjournals.aje.a009713

[7] Gurgel, R.K., Ward, P.D., Schwartz, S., Norton, M.C., Foster, N.L. and Tschanz, J.T. (2014) Relationship of Hearing Loss and Dementia: A Prospective, Population-Based Study. Otology \& Neurotology, 35, 775-781. https://doi.org/10.1097/MAO.0000000000000313

[8] Gopinath, B., Wang, J.J., Schneider, J., Burlutsky, G., Snowdon, J., McMahon, C.M., et al. (2009) Depressive Symptoms in Older Adults with Hearing Impairments: The Blue Mountains Study. Journal of the American Geriatrics Society, 57, 1306-1308. https://doi.org/10.1111/j.1532-5415.2009.02317.x

[9] Institut National de la Statistique et de l'Analyse Économique (INSAE) (2013) RGPH4: Que retenir des effectifs de population en 2013? https://insae.bj/statistiques/statistiques-demographiques/40-statistiques-demograph iques

[10] Abdel-Hamid, O., Khatib, O.M.N., Aly, A., Morad, M. ad Kamel, S. (2007) Prevalence and Patterns of Hearing Impairment in Egypt: A National Household Survey. Eastern Mediterranean Health Journal, 13, 1170-1180.

https://doi.org/10.26719/2007.13.5.1170

[11] Noble, W. and Gatehouse, S. (2004) Interaural Asymmetry of Hearing Loss, Speech, Spatial and Qualities of Hearing Scale (SSQ) Disabilities, and Handicap. International Journal of Audiology, 43, 100-114. https://doi.org/10.1080/14992020400050015

[12] Ambert-Dahan, E., Laouénan, C., Lebredonchel, M., Borel, S., Carillo, C., Bouccara, D., et al. (2018) Evaluation of the Impact of Hearing Loss in Adults: Validation of a Quality of Life Questionnaire. European Annals of Otorhinolaryngology, Head and Neck Diseases, 135, 25-31. https://doi.org/10.1016/j.anorl.2017.09.003

[13] Valero-García, J. and Vila-Rovira, J.M. (2018) Descriptive Study on the Prevalence of Presbycusis among a Population in the Industrial Belt of Barcelona by Exploring a Random Sample of Primary Healthcare Center Users. European Journal of Investigation in Health, Psychology and Education, 8, 79-90. 
https://doi.org/10.30552/ejihpe.v8i2.246

[14] Cruickshanks, K. and Wichmann, M. (2012) Hearing Impairment and Other Health Conditions in Older Adults: Chance Associations or Opportunities for Prevention? Seminars in Hearing, 33, 217-224. https://doi.org/10.1055/s-0032-1315720

[15] Lin, F.R., Thorpe, R., Gordon-Salant, S. and Ferrucci, L. (2011) Hearing Loss Prevalence and Risk Factors among Older Adults in the United States. The Journals of Gerontology Series A: Biological Sciences and Medical Sciences, 66A, 582-590. https://doi.org/10.1093/gerona/glr002

[16] Folorunso, D., Dahilo, E., Gbujie, I., Damtong, F., Quadri, O., Nwakwo, B., et al. (2020) Age-Related Hearing Loss at Gwagwalada Area Council of Federal Capital Territory, Abuja. Nigerian Journal of Clinical Practice, 23, 1494-1499. https://doi.org/10.4103/njcp.njcp $390 \_19$

[17] Nash, S.D., Cruickshanks, K.J., Klein, R., Klein, B.E.K., Nieto, F.J., Huang, G.H., et al. (2011) The Prevalence of Hearing Impairment and Associated Risk Factors: The Beaver Dam Offspring Study. Archives of Otorhinolaryngology-Head \& Neck Surgery, 137, 432-439. https://doi.org/10.1001/archoto.2011.15

[18] Hannula, S., Bloigu, R., Majamaa, K., Sorri, M. and Mäki-Torkko, E. (2011) SelfReported Hearing Problems among Older Adults: Prevalence and Comparison to Measured Hearing Impairment. Journal of the American Academy of Audiology, 22, 550-559. https://doi.org/10.3766/jaaa.22.8.7

[19] Roth, T.N., Hanebuth, D. and Probst, R. (2011) Prevalence of Age-Related Hearing Loss in Europe: A Review. European Archives of Oto-Rhino-Laryngology, 268, 11011107. https://doi.org/10.1007/s00405-011-1597-8

[20] Lasisi, A.O., Abiona, T. and Gureje, O. (2010) The Prevalence and Correlates of Self-Reported Hearing Impairment in the Ibadan Study of Ageing. Transactions of The Royal Society of Tropical Medicine and Hygiene, 104, 518-523. https://doi.org/10.1016/j.trstmh.2010.03.009

[21] Catala, M. (2014) Embryologie de l'oreille Interne [20-005-A-40]. EM Consulte. https://www.em-consulte.com/article/873378/complements/embryologie-de-1-oreill e-interne

[22] de Sousa, C.S., de Castro, N., Larsson, E.J. and Ching, T.H. (2009) Risk Factors for Presbycusis in a Socio-Economic Middle-Class Sample. Brazilian Journal of Otorhinolaryngology, 75, 530-536. https://doi.org/10.1590/S1808-86942009000400011

[23] Helzner, E.P., Cauley, J.A., Pratt, S.R., Wisniewski, S.R., Zmuda, J.M., Talbott, E.O., et al. (2005) Race and Sex Differences in Age-Related Hearing Loss: The Health, Aging and Body Composition Study. Journal of the American Geriatrics Society, 53, 21192127. https://doi.org/10.1111/j.1532-5415.2005.00525.x

[24] Lien, K.-H. and Yang, C.-H. (2021) Sex Differences in the Triad of Acquired Sensorineural Hearing Loss. International Journal of Molecular Sciences, 22, Article No. 8111. https://doi.org/10.3390/ijms22158111

[25] Amplifon (2020) La différence de perte auditive entre hommes et femmes. https://www.amplifon.com/fr-be/blog/femmes-hommes-difference-perte-auditive

[26] Sogebi, O.A., Olusoga-Peters, O.O. and Oluwapelumi, O. (2013) Clinical and Audiometric Features of Presbycusis in Nigerians. African Health Sciences, 13, 886-892. https://doi.org/10.4314/ahs.v13i4.4

[27] Hervier, B., Bordure, P., Masseau, A., Calais, C., Agard, C., Hamidou, M. (2010) Surdités auto-immunes: Bases pathogéniques et applications thérapeutiques. La Revue de Médecine Interne, 31, 222-228. https://doi.org/10.1016/j.revmed.2008.12.017 
[28] Bouata, R., Bhouri, N., Khélifa, M., Jellali, S., Kadi, S., Harrathi, K., et al. (2019) Presbyacousie chez le sujet âgé: Retentissement sur la qualité de vie et prise en charge. Journal Tunisien d ORL et de Chirurgie Cervico-Faciale, 1, 25-29.

[29] Friedman, R.A., Van Laer, L., Huentelman, M.J., Sheth, S.S., Van Eyken, E., Corneveaux, J.J., et al. (2009) GRM7 Variants Confer Susceptibility to Age-Related Hearing Impairment. Human Molecular Genetics, 18, 785-796. https://doi.org/10.1093/hmg/ddn402

[30] Newman, D.L., Fisher, L.M., Ohmen, J., Parody, R., Fong, C.-T., Frisina, S.T., et al. (2012) GRM7 Variants Associated With age-Related Hearing Loss Based on Auditory Perception. Hearing Research 294, 125-132. https://doi.org/10.1016/j.heares.2012.08.016

[31] Jayakody, D.M.P, Friedland, P.L., Martins, R.N. and Sohrabi, H.R. (2018) Impact of Aging on the Auditory System and Related Cognitive Functions: A Narrative Review. Frontiers in Neuroscience, 12, Article No. 125. https://doi.org/10.3389/fnins.2018.00125

[32] Ramage-Morin, P.L. (2016) Hearing Difficulties and Feelings of Social Isolation among Canadians Aged 45 or Older. Health Reports, 27, 3-12.

[33] Espmark, A.-K.K. and Scherman, M.H. (2003) Hearing Confirms Existence and Identity-Experiences from Persons with Presbycusis: La audición confirma la existencia y la identidad: Experiencias de personas con presbiacusia. International Journal of Audiology, 42, 106-115. https://doi.org/10.3109/14992020309078341

[34] Leusie, S. (2015) Privation sensorielle auditive et réhabilitation chez le sujet âgé: Conséquences sur le fonctionnement cognitif. Thèse, Université Claude Bernard-Lyon I, Villeurbanne. https://tel.archives-ouvertes.fr/tel-01148565 


\section{Survey Form}

\section{Sheet $\mathrm{N}^{\circ} \ldots \ldots$.}

Date of investigation $/ . \ldots \ldots . . . / \ldots \ldots . . . . . . . . . . /$

Address. Phone.

\section{SESSION A: SOCIO-DEMOGRAPHIC AND CULTURAL FACTORS}

\begin{tabular}{|c|c|c|c|c|c|}
\hline A1 & Age $/ \ldots . /$ yea & & & & \\
\hline A2 & Gender & $1=$ Male $2=$ Femal & & & I..... \\
\hline A3 & Profession & $\begin{array}{l}1=\text { Private employee } \\
4=\text { Entrepreneur } \\
7=\text { Housewife }\end{array}$ & $\begin{array}{l}2=\text { Public employee } \\
5=\text { farmer } \\
8=\text { craftsman }\end{array}$ & $\begin{array}{l}3=\text { Retired } \\
6=\text { shopkeeper } \\
9=\text { Others (specify) }\end{array}$ & $\mid \ldots . . /$ \\
\hline A4 & Ethnic group & $\begin{array}{l}1=\text { Dendi } \\
4=\text { Yoruba and assoc } \\
6=\text { Ditamari and asso }\end{array}$ & $\begin{array}{l}2=\text { Bariba } \\
\text { lates } \\
\text { ciates }\end{array}$ & $\begin{array}{l}3=\text { Fon and associates } \\
5=\text { Peuhl } \\
7=\text { Others }(\text { specify }) \ldots \ldots \ldots \ldots \ldots \ldots\end{array}$ & $|\ldots .|$. \\
\hline A5 & Religion & $\begin{array}{l}1=\text { Muslim } \\
4=\text { Other (to be speci }\end{array}$ & $\begin{array}{l}2=\text { Christian } \\
\text { fied ................) }\end{array}$ & $3=$ Endogenous & $|\ldots .|$. \\
\hline A6 & Level of educa & Ional $\begin{aligned} 1 & =\text { Literate } \\
4 & =\text { Secondary }\end{aligned}$ & $\begin{array}{l}2=\text { Illiterate } \\
5=\text { University }\end{array}$ & $3=$ Primary & $|\ldots .|$. \\
\hline A7 & Noise exposur & $1=\mathrm{Yes}$ & $2=\mathrm{No}$ & & I..... \\
\hline
\end{tabular}

\section{SESSION B: SYMPTOMS}

\begin{tabular}{|c|c|c|c|c|c|}
\hline B1 & Hearing loss & $1=$ yes & & & I..... \\
\hline B1a & If yes, specify the side & $1=$ Right unilateral & $2=$ Left unilateral & $3=$ Bilateral & I..... \\
\hline B2 & Tinnitus & $1=$ yes & $2=\mathrm{No}$ & & I..... \\
\hline B2a & If yes, specify the side & $1=$ Right unilateral & $2=$ Left unilateral & $3=$ Bilateral & $\mid \ldots . . /$ \\
\hline B3 & Otalgia & $1=$ yes & $2=\mathrm{No}$ & & $\mid \ldots . . /$ \\
\hline B3a & If yes, specify side & $1=$ Unilateral right & $2=$ Left unilateral & $3=$ Bilateral & $\mid \ldots . . /$ \\
\hline B4 & Otorrhea & $1=$ yes & $2=\mathrm{No}$ & & $|\ldots .|$. \\
\hline $\mathrm{B} 4 \mathrm{a}$ & If yes, specify the side & $1=$ Right unilateral & $2=$ Left unilateral & $3=$ Bilateral & $|\ldots .|$. \\
\hline B6 & Vertigo & $1=$ yes & $2=\mathrm{No}$ & & $|\ldots .|$. \\
\hline B6a & If yes, specify: & $1=$ Brief & $2=$ Durable & & I..... \\
\hline B7 & Other associated sym & nptoms /.... & $\ldots . . . .$. & & \\
\hline
\end{tabular}

\section{SESSION C: HISTORY OF THE RESPONDENT}

\begin{tabular}{|c|c|c|c|c|c|}
\hline $\mathrm{C} 1$ & Medical history: & $\begin{array}{l}1=\text { Diabetes } \\
4=\text { Osteoarthritis } \\
6=\text { None }\end{array}$ & $\begin{array}{l}2=\text { high blood pressure }(\mathrm{HBP}) \\
5=\text { Others: to be specified } /\end{array}$ & $\begin{array}{l}3=\text { Asthma } \\
\text { / }\end{array}$ & I..... \\
\hline $\mathrm{C} 2$ & \multicolumn{3}{|c|}{ ENT surgical history $1=$ Yes (if yes, please specify ..................) } & $2=$ No & $|\ldots .|$. \\
\hline $\mathrm{C} 3$ & \multicolumn{2}{|c|}{ Family history of age-related hearing loss } & $1=$ Yes & $2=\mathrm{No}$ & I.....I \\
\hline $\mathrm{C} 4$ & Therapeutic & & & & \\
\hline
\end{tabular}




\section{Continued}

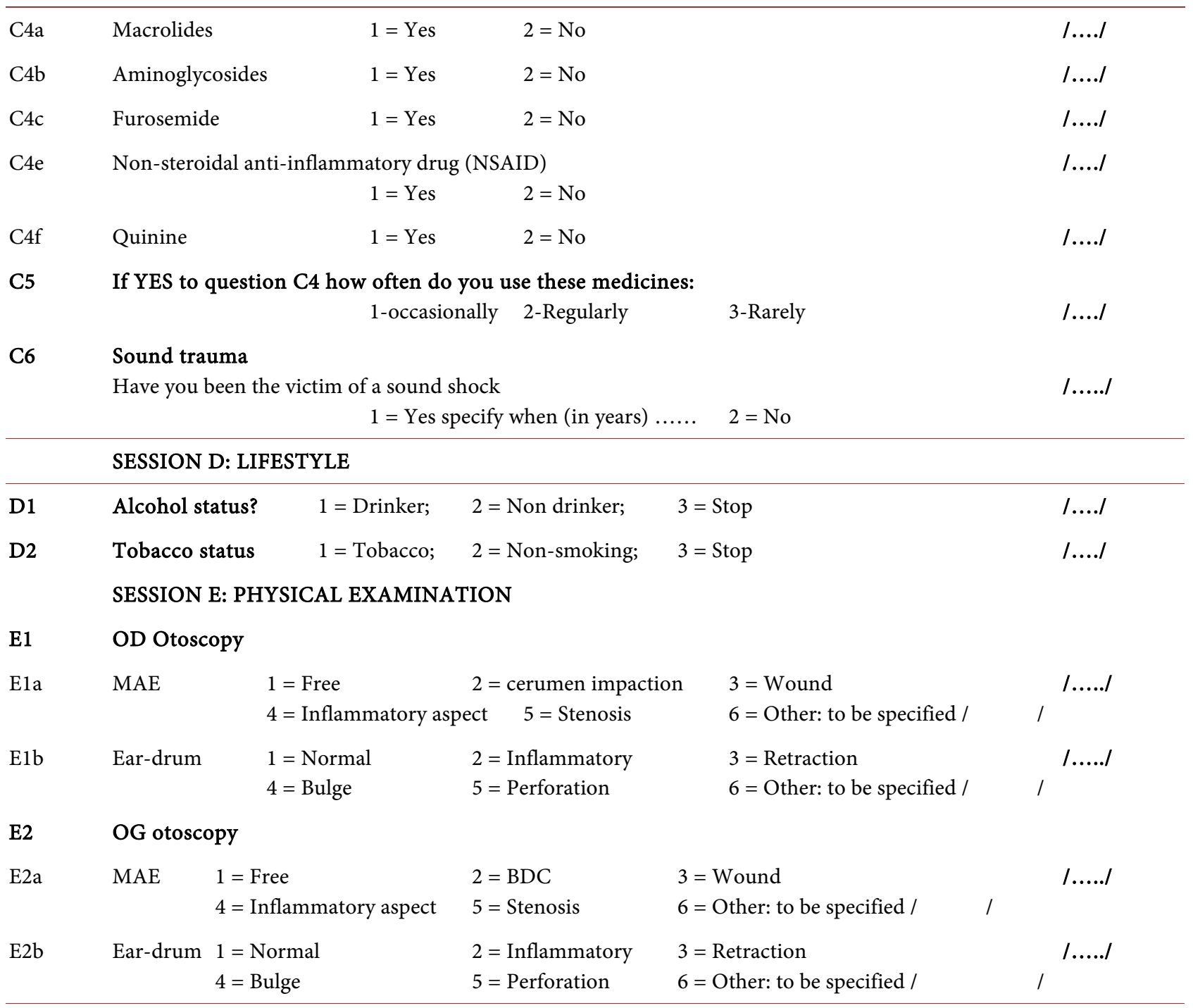

\section{SESSION F: TONAL AUDIOMETRY}

F1 Type of deafness

\begin{tabular}{|c|c|c|c|c|}
\hline F1a & \multirow[t]{2}{*}{ Right side: } & $1=$ Normal hearing & $2=$ Conductive deafness & \multirow[t]{2}{*}{$|\ldots .|}$. \\
\hline & & $3=$ Sensorineural deafness & $4=$ Mixed deafness & \\
\hline \multirow[t]{2}{*}{ F1b } & Left side: & $1=$ Normal hearing & $2=$ Conductive hearing loss & $|\ldots .|$. \\
\hline & & $3=$ Sensory deafness & $4=$ Mixed hearing loss & \\
\hline
\end{tabular}

\section{F2 Average hearing loss}

$\begin{array}{ll}\text { F2a } & \text { Right ear }=/ \ldots \ldots \ldots / \mathrm{dB} \\ \text { F2b } & \text { Left ear }=/ \ldots \ldots \ldots . \mathrm{dB}\end{array}$

F3 Degree of deafness

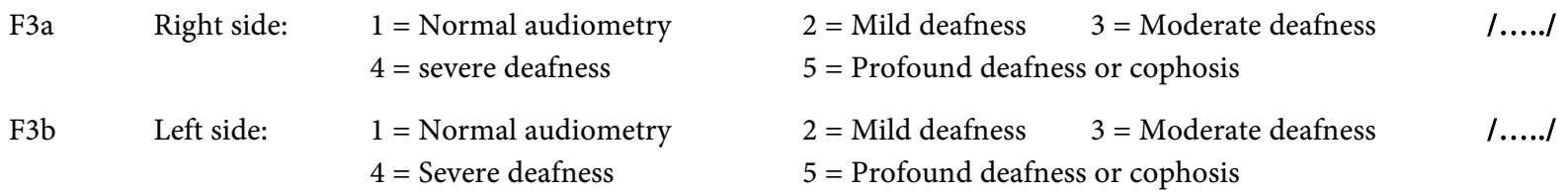




\section{Continued}

\section{SESSION G: DIAGNOSIS}

G1 Diagnosis of presbycusis $\quad 1=$ yes $\quad 2=$ No $\quad / \ldots . . /$

(If YES to question $\mathrm{G1}$, answer session $\mathrm{H}$ )

SESSION H: SOCIO-PROFESSIONAL IMPACT

\section{H1 Quality of life}

H1a How do you rate your quality of life?
Not satisfactory
Moderately satisfactory
Satisfactory

\begin{tabular}{l} 
(2) \\
\hline 1
\end{tabular}

H1b Do you feel independent in your daily life?
Not at all
More or less

Totally

\begin{tabular}{|c|c|c|c|c|c|c|c|c|c|}
\hline 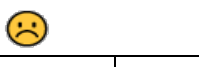 & \multicolumn{4}{|c|}{$\odot$} & \multicolumn{5}{|c|}{ (:) } \\
\hline 1 & 2 & 3 & 4 & 5 & 6 & 7 & 8 & 9 & 10 \\
\hline
\end{tabular}

H1c How is your morale just now?

Not satisfactory
\begin{tabular}{|c|c|c|c|c|c|c|c|c|c|} 
Moderately satisfactory & Satisfactory \\
$(2)$ & 2 & 3 & 4 & 5 & 6 & 7 & 8 & 9 & 10 \\
\hline 1 & 2 &
\end{tabular}

H1d Are you usually self-confident?

Not at all
\begin{tabular}{|c|c|c|c|c|c|c|c|c|c|} 
More or less & Totally \\
$(2)$ & $(-)$ & 5 & 6 & 7 & 8 & 9 & 10 \\
\hline 1 & 2 & 3 & 4 & 5 &
\end{tabular}

H1e Do you feel like taking on new projects?
Not at all
More or less
Totally

\begin{tabular}{|c|c|c|c|c|c|c|c|c|c|}
\hline$\partial$ & \multicolumn{4}{|c|}{$\odot$} & \multicolumn{5}{|c|}{$(9)$} \\
\hline 1 & 2 & 3 & 4 & 5 & 6 & 7 & 8 & 9 & 10 \\
\hline
\end{tabular}

H2 Personal life

$\mathrm{H} 2 \mathrm{a} \quad$ What is communication with friends and family like?

\begin{tabular}{|c|c|c|c|c|c|c|c|c|c|}
\hline $\begin{array}{l}\text { Very } \\
\odot\end{array}$ & & & kay & & & & & erv & \\
\hline 1 & 2 & 3 & 4 & 5 & 6 & 7 & 8 & 9 & 10 \\
\hline
\end{tabular}

$\mathrm{H} 2 \mathrm{~b} \quad$ Can you follow a conversation without knowing what it's about in advance? Not at all More or less

Totally

\begin{tabular}{|c|c|c|c|c|c|c|c|c|c|}
\hline$\dot{\partial}$ & & \multicolumn{3}{|c|}{$\odot$} & \multicolumn{5}{|c|}{ (9) } \\
\hline 1 & 2 & 3 & 4 & 5 & 6 & 7 & 8 & 9 & 10 \\
\hline
\end{tabular}

$\mathrm{H} 2 \mathrm{c} \quad$ Can you join in a conversation with several others in a quiet setting?

\begin{tabular}{|c|c|c|c|c|c|c|c|c|c|}
\hline \multirow{2}{*}{$\begin{array}{l}\text { Never } \\
\qquad{ }^{1}\end{array}$} & & \multicolumn{3}{|c|}{$\begin{array}{l}\text { Sometimes } \\
\odot=\end{array}$} & & & \multicolumn{3}{|c|}{ usually } \\
\hline & 2 & 3 & 4 & 5 & 6 & 7 & 8 & 9 & 10 \\
\hline
\end{tabular}

H2d Are you okay talking in a noisy setting (Family gathering, TV, dinner, etc.)?
Not at all
More or less
Totally

\begin{tabular}{l} 
(2) \\
\hline 1
\end{tabular}




\section{Continued}

$\mathrm{H} 2 \mathrm{e} \quad$ Are you self-confident enough to start a discussion with friends or familly?

Not at all

6
More or less

(-)

Totally

\begin{tabular}{|l|l|l|l|l|l|l|l|l|l|}
\hline 1 & 2 & 3 & 4 & 5 & 6 & 7 & 8 & 9 & 10 \\
\hline
\end{tabular}

H3

Social life

H3a Do you have a satisfactory social life despite your hearing loss?

Not at all

More or less

Totally

(6)

(-)

\begin{tabular}{|l|l|l|l|l|l|l|}
\hline 4 & 5 & 6 & 7 & 8 & 9 & 10 \\
\hline
\end{tabular}

$\mathrm{H} 3 \mathrm{~b}$

Do you feel at ease in social groups you're part of (Sports club, association, activities, neighborhood)?
Not at all
More or less
Totally

6

$(-)$

\begin{tabular}{|l|l|l|l|l|l|l|l|l|l|}
1 & 2 & 3 & 4 & 5 & 6 & 7 & 8 & 9 & 10 \\
\hline
\end{tabular}

H3c Are you happy to be in direct contact with friends? (face to face, telephone, etc.)?
Not at all
More or less
Totally

\begin{tabular}{|c|c|c|c|}
\hline & & & \\
\hline 1 & 2 & 3 & \\
\hline
\end{tabular}

H3d Do you easily approach people you don't know?
Not at all
More or less
Totally

(-)
\begin{tabular}{|c|c|c|c|c|c|c|c|c|c|}
\hline 1 & 2 & 3 & 4 & 5 & 6 & 7 & 8 & 9 & 10 \\
\hline
\end{tabular}

$\mathrm{H} 3 \mathrm{e}$

Are you okay talking when there are several conversations going on around you?
Not at all
More or less
Totally

(2)
\begin{tabular}{|c|c|c|c|c|c|c|c|c|c|}
\hline 1 & 2 & 3 & 4 & 5 & 6 & 7 & 8 & 9 & 10 \\
\hline
\end{tabular}

H4

\section{Professional life}

H4a Do you have a job? 1 = yes $0=$ No If you answered yes, go on to the next 5 questions

$\mathrm{H} 4 \mathrm{~b} \quad$ Are you at ease in your relations at work?
Not at all
More or less
Totally

(2)
\begin{tabular}{|c|c|c|c|c|c|c|c|c|c|}
\hline 1 & 2 & 3 & 4 & 5 & 6 & 7 & 8 & 9 & 10 \\
\hline
\end{tabular}

$\mathrm{H} 4 \mathrm{c} \quad$ Do you feel at ease taking part in meetings at work (joining in the discussion)?

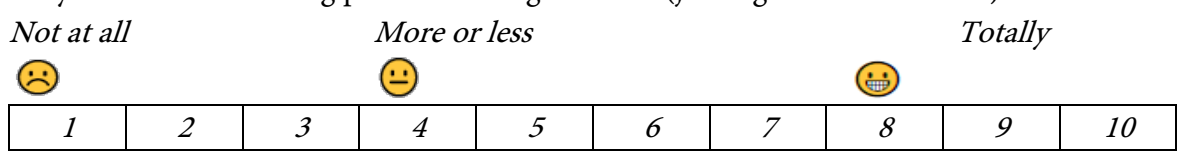

$\mathrm{H} 4 \mathrm{~d} \quad$ Do you feel at ease is special situations like using the phone, using a foreign language?

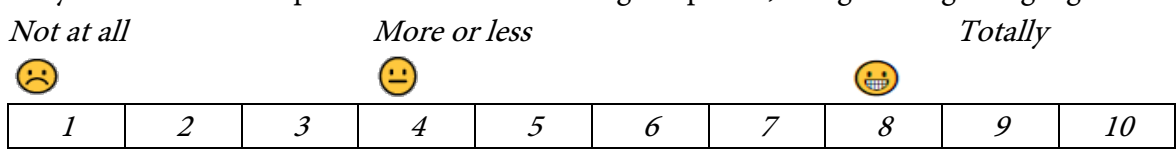

$\mathrm{H} 4 \mathrm{e} \quad$ Do you think you could make new acquaintances at work? (Foreign languages skills, training courses, etc.)?
Not at all
More or less
Totally

\begin{tabular}{l} 
(2) \\
\hline 1
\end{tabular}




\section{Continued}

$\mathrm{H} 4 \mathrm{f} \quad$ Do you think you can progress in your work despite your hearing loss? Not at all More or less

Totally

\begin{tabular}{l} 
(2) \\
\hline 1
\end{tabular}

